\title{
Comparative study of antioxidant activity of imported tropical and subtropical fruits
}

\author{
Hai-Jung Chung* \\ Department of Food Science and Nutrition, Daejin University, Pocheon 11159, Korea
}

\section{수입산 열대·아열대 과일의 항산화 활성 비교연구}

\author{
정해정* \\ 대진대학교 식품영양학과
}

\begin{abstract}
The objective of this study was to investigate the antioxidant activity of imported tropical and subtropical fruits including dragon fruits, green kiwi, papaya, pineapple, pomegranate, and yellow mango. A seventy percent of ethanol extracts were prepared. Total phenolic content, DPPH (1,1-diphenyl-2-picryl hydrazyl)-, ABTS (2,2'-azino-bis (3-ethylbenzothiazoline-6-sulfonic acid)), superoxide anion radical scavenging activity, FRAP (ferric reducing antioxidant power), tyrosinase inhibitory activity, and reducing power were investigated for the comparisons of antioxidant activities. The phenolic content expressed as gallic acid equivalents (GAE) was found to be highest in pomegranate (12.22 $\mathrm{mg}$ GAE/g), followed by pineapple (3.77 mg GAE/g). Pomegranate and pineapple exhibited higher antioxidant activity than those of other fruits except for FRAP. DPPH and ABTS radical scavenging activity from pomegranate were $93.00 \%$, and $98.98 \%$, respectively, at a concentration of $5 \mathrm{mg} / \mathrm{mL}$, which were equal to those of ascorbic acid used for a positive control.
\end{abstract}

Key words : dragon fruit, kiwi, papaya, pineapple, antioxidant

\section{서 론}

경제가 발전하고 생활수준이 향상됨에 따라 소비자들의 건강에 대한 관심은 날로 높아져서 식품이 단지 생명유지 기능과 기호적 기능을 제공하는 것 외에 질병예방, 면역력 강화, 노화방지와 같은 생리활성 기능도 제공해 줄 것을 기대하고 있다(1,2) 건강증진 및 질병예방효과가 있는 식품 을 섭취하려는 소비자의 요구 증가에 따라 식품업계 및 학계에서는 건강 기능성을 충족시키는 식품소재 개발에 관심을 가지고 특히 식물성 소재 개발 및 이를 이용한 기능 성 제품개발 연구가 활발히 진행되고 있다. 여러 식물성 자원 중 과일은 독특한 맛과 향, 색 등으로 소비자들의 애호

*Corresponding author. E-mail : haijung@daejin.ac.kr Phone : 82-31-539-1861, Fax : 82-31-539-1860

Received 2 June 2015; Revised 24 July 2015; Accepted 28 July 2015.

Copyright (c) The Korean Society of Food Preservation. All rights reserved.
를 받을 뿐 만 아니라 항산화능이 뛰어나고 충분한 양을 섭취하면 만성질환 예방에 효과가 큰 것으로 알려져 있다 $(3,4)$. 이는 과일에 함유되어 있는 비타민, 카로티노이드, 폴리페놀 등의 생리활성 성분에 의한 것으로 보고되고 있는 데(5) 그 중에서도 폴리페놀은 superoxide, hydroxyl, peroxyl 등과 같은 free radical에 의해 생성되는 산화적 스트레스 (oxidative stress)를 효과적으로 감소시킴으로써 암, 심장병, 동맥경화, 관절염 및 퇴행성 질환의 예방 및 감소에 기여하 는 것으로 보고되고 있다(2,6-8). 산화적 스트레스를 효과적 으로 예방 또는 감소시키기 위해서는 외부로부터 충분한 양의 항산화물질을 섭취해야 하는데(9) 그 공급원으로 과일 은 여러 식물성 소재 중 건강 기능성이 가장 우수하여 소비 자들이 쉽게 이용할 수 있다.

최근 열대 - 아열대 과일의 소비가 국내외적으로 증가하 고 있는데(10) 우리나라에서도 생활수준의 향상과 더불어 매년 수입되는 양과 종류가 증가하며 소비자들에게 다양한 종류의 과일을 접할 수 있는 기회를 제공하고 있다. 특히 1994년에 이루어진 UR 협상을 시작으로 FTA 등의 무역 
자유화 협상을 통하여 수입 과일 시장이 본격적으로 개방되 면서 저렴한 가격으로 구입이 가능하게 되어 수입 과일은 더 이상 특별하지 않은 일상적인 소비 품목이 되었다(11). 열대 - 아열대 과일은 이국적인 향미와 관능적 특성을 가지 고 있을 뿐 만 아니라 영양적 가치가 우수하며 생리활성 물질이 다양하게 함유되어 있는 것으로 밝혀져 $(12,13)$ 많은 연구들이 이루어지고 있다. 그러나 국내에서는 열대 - 아열 대 과일에 대한 기능성 연구 보고가 그리 많지 않은 실정이 므로 본 연구에서는 수입되는 열대 - 아열대 과일 중 일부를 선택하여 항산화 활성을 측정하고 비교함으로써 이 분야에 기초자료를 제공하고자 하였다.

\section{재료 및 방법}

\section{실험재료}

본 실험에 사용한 수입 과일은 그린키위(green kiwi, 뉴질 랜드산), 석류(pomegranate, 미국산), 옐로우망고(yellow mango, 필리핀산), 용과(dragon fruit, 베트남산), 파인애플 (pineapple, 필리핀산), 파파야(papaya, 필리핀산) 등 6종으 로 서울소재 대형마트에서 2014년 9월에 구입하였다. 이들 각각의 껍질을 제거하고 조직을 파쇄한 후 동결건조기 (TFD, Ilshin, Seoul, Korea)를 이용하여 건조한 다음 분말화 하여 $-20^{\circ} \mathrm{C}$ 에 냉동보관하며 사용하였다. Folin-ciocalteau's phenol reagent, gallic acid, 1,1-diphenyl-2-picryl hydrazyl (DPPH), 2,2'-azino-bis(3-ethylbenzothiazoline-6-sulfonic acid) (ABTS), potassium persulfate, xanthine, xanthine oxidase, nitroblue tetrazolium(NBT), potassium ferricyanide, 2, 4, 6-tri-2-pyridyl-1, 3, 5-triazine(TPTZ), mushroom tyrosinase 등은 Sigma-Aldrich(St. Louis, MO, USA)에서 구입하였고 그 외의 시약은 특급 및 일급시약을 구입하여 사용하였다.

\section{추출액의 제조}

각각의 분말 시료에 20 배의 $70 \%$ 에탄올을 가하고 $30^{\circ} \mathrm{C}$ 에 서 12 시간 추출하는 과정을 2 회 반복 실시하였다. 추출액을 여과지(Whatman filter paper No.1)로 여과한 후 진공농축기 (Buchi R-114, Flawil, Switzerland)로 감압농축하여 동결 건 조시킨 다음 일부를 취하여 $1,2.5,5 \mathrm{mg} / \mathrm{mL}$ 의 농도가 되도 록 50\% dimethyl sulfoxide에 용해하여 시료를 제조하였으 며, 양성대조군으로는 ascorbic acid를 $1 \mathrm{mg} / \mathrm{mL}$ 농도로 제조 하여 사용하였다.

\section{총 폴리페놀 함량 측정}

총 폴리페놀 함량은 Dewanto 등(14)의 방법에 따라 각 시료용액 $0.1 \mathrm{~mL}$ 에 증류수 $1.9 \mathrm{~mL}$ 와 Folin-Ciocalteau's phenol reagent $0.2 \mathrm{~mL}$ 를 가하여 실온에서 3 분간 반응시켰 다. 여기에 포화 $\mathrm{Na}_{2} \mathrm{CO}_{3}$ 용액 $0.4 \mathrm{~mL}$ 와 증류수 $1.9 \mathrm{~mL}$ 를
가하여 혼합하고 실온에서 1시간 반응시킨 후 $725 \mathrm{~nm}$ (Smart Plus SP-1900PC, Seoul, Korea)에서 흡광도를 측정하 였다. 총 폴리페놀 함량은 $\mathrm{mg}$ gallic acid equivalents (GAE) /g으로 나타내었다.

\section{$\mathrm{DPPH}$ radical 소거능 측정}

시료용액의 DPPH radical 소거능은 Blois의 방법(15)에 따라 $0.1 \mathrm{mM} \mathrm{DPPH}$ 용액 $2 \mathrm{~mL}$ 에 시료용액 $0.4 \mathrm{~mL}$ 를 가하여 잘 혼합하고 실온에서 30 분간 반응시킨 후 $517 \mathrm{~nm}$ 에서 흡광도를 측정하여 시료용액 첨가군과 무첨가군 간의 흡광 도 비(\%)로 나타내었다.

\section{ABTS radical 소거능 측정}

시료 용액의 ABTS radical 소거능은 Re 등(16)의 방법을 일부 변형하여 측정하였다. 즉, $\mathrm{ABTS}$ 용액과 $2.45 \mathrm{mM}$ potassium persulfate를 14:1로 혼합 $(\mathrm{v} / \mathrm{v})$ 하여 실온의 암소에 서 20시간 방치한 후 증류수를 가하여 $734 \mathrm{~nm}$ 에서의 흡광 도값이 0.70 내외가 되도록 희석하였다. 이 중 $1.6 \mathrm{~mL}$ 를 취하여 시료용액 $0.1 \mathrm{~mL}$ 를 가하고 실온에서 5 분간 방치한 다음 $734 \mathrm{~nm}$ 에서 흡광도를 측정하여 시료용액 첨가군과 무첨가군 간의 흡광도 비(\%)로 나타내었다.

\section{Superoxide anion radical 소거능 측정}

시료용액의 superoxide anion radical 소거능은 Wang 등 (17)의 방법을 약간 응용하였다. 즉, 각 시료용액 $0.4 \mathrm{~mL}$ 에 $0.4 \mathrm{mM}$ xanthine과 $0.24 \mathrm{mM} \mathrm{NBT}$ 를 1:1로 혼합한 용액 $1 \mathrm{~mL}$, xanthine oxidase $(0.049$ unit $/ \mathrm{mL}) 0.75 \mathrm{~mL}$ 를 가한 다음 $37^{\circ} \mathrm{C}$ 에서 40 분간 반응시켰다. 여기에 $69 \mathrm{mM}$ SDS $2 \mathrm{~mL}$ 를 가하여 반응을 정지시킨 다음 $560 \mathrm{~nm}$ 에서 흡광도를 측정하 여 시료용액 첨가군과 무첨가군의 흡광도 비(\%)로 나타내 었다.

Ferric ion reducing antioxidant power(FRAP) 측정

FRAP은 Benzie 등(18)의 방법을 변형하여 측정하였다. 즉, $300 \mathrm{mM}$ acetate buffer(pH 3.6)와 $40 \mathrm{mM} \mathrm{HCl}$ 에 녹인 $10 \mathrm{mM}$ TPTZ 및 $20 \mathrm{mM}$ ferric chloride를 $10: 1: 1(\mathrm{v} / \mathrm{v})$ 의 비율로 혼합하여 FRAP용액을 제조한 다음 시료용액 0.2 $\mathrm{mL}$ 에 FRAP용액 $2 \mathrm{~mL}$ 를 가하여 실온에서 4 분간 반응시킨 후 $593 \mathrm{~nm}$ 에서 흡광도를 측정하였다.

\section{Tyrosinase 저해 효과 측정}

시료용액의 tyrosinase 저해 효과는 Chang 등(19)의 방법 을 변형하여 측정하였다. 즉, $10 \mathrm{mM} \mathrm{L-DOPA} 0.04 \mathrm{~mL}$ 와 $0.175 \mathrm{M}$ phosphate buffer(pH 6.8) $2 \mathrm{~mL}$ 에 시료용액 0.5 $\mathrm{mL}$ 를 가하여 잘 혼합하였다. 여기에 mushroom tyrosinase (110 unit/mL) $0.04 \mathrm{~mL}$ 를 가하고 $35^{\circ} \mathrm{C}$ 에서 2 분간 반응시킨 다음 $475 \mathrm{~nm}$ 에서 흡광도를 측정하여 시료용액 첨가군과 
무첨가군 간의 흡광도 비(\%)로 나타내었다.

\section{환원력 측정}

시료용액의 환원력(reducing power)은 Wong 등(20)의 방 법을 변형하여 측정하였다. 즉, 각 시료용액 $0.5 \mathrm{~mL}$ 에 0.2 $\mathrm{M}$ phosphate buffer(pH 6.6) $0.5 \mathrm{~mL}$ 와 $1 \%$ potassium ferricyanide $0.5 \mathrm{~mL}$ 를 혼합하여 $50^{\circ} \mathrm{C}$ 에서 20 분간 반응시킨 다음 $10 \% \mathrm{TCA}$ 용액 $0.5 \mathrm{~mL}$ 와 $0.1 \% \mathrm{FeCl}_{3} 0.2 \mathrm{~mL}$ 를 가하여 잘 혼합한 후 $700 \mathrm{~nm}$ 에서 흡광도를 측정하였다.

\section{통계처리}

모든 실험은 3회 이상 반복 측정하였고 $\operatorname{SPSS}(12.0, \mathrm{SPSS}$ Inc., Chicago, IL, USA)를 이용하여 평균표준편차로 표시 하였다. 각 실험군 간의 차이는 유의수준 $\mathrm{p}<0.05$ 에서 분산 분석(ANOVA)으로 분석한 다음 Duncan's multiple range test로 평균치간의 유의적 차이를 검증하였다.

\section{결과 및 고찰}

\section{총 폴리페놀 함량}

폴리페놀 화합물은 flavonoid, isoflavone, flavone, anthocyanin, tannin, catechin 등을 총칭하는 것으로 과일을 포함한 식물계에 널리 분포되어 있다 $(5,21)$. 폴리페놀에 존 재하는 다수의 hydroxyl $(-\mathrm{OH})$ 기는 단백질 및 여러 화합물 과 결합하는 특성이 있어 항산화, 항암, 항염, 시력증진 효과 가 우수한 것으로 보고되고 있다(21-23). 열대·아열대 과일 을 $70 \%$ 에탄올로 추출한 후 총 폴리페놀 함량을 측정한 결과는 Table 1 과 같다. 석류가 $12.22 \mathrm{mg} \mathrm{GAE} / \mathrm{g}$ 으로 가장 높게 나타났고 파인애플이 $3.77 \mathrm{mg} \mathrm{GAE} / \mathrm{g}$ 으로 그 다음으 로 높았으며 용과, 그린키위, 파파야, 옐로우망고가 2.45 2.99 mg GAE/g으로 나타났다(p<0.05). Hossain 등 (24)은 파인애플 메탄올 추출물의 폴리페놀 함량을 51.1 $\mathrm{mg}$ caffeic acid equivalent/g으로 보고하였고 Ozgen 등(25) 은 6 품종 석류의 총 페놀 함량 분석결과 $124.5 ~ 207.6 \mathrm{mg}$ $\mathrm{GAE} / 100 \mathrm{~mL}$ 의 범위라고 보고하였다. Liu 등(26)은 4 종류 망고의 총 페놀 함량이 $22.27 ~ 139.71 \mathrm{mg} \mathrm{GAE} / 100 \mathrm{~g}$ 으로 품종에 따라 차이가 있음을 보고하였고 Patthamakanokporn 등(27)은 망고와 파파야의 폴리페놀 함량을 $71 \sim 113 \mathrm{mg}$ $\mathrm{GAE} / 100 \mathrm{~g}$ 과 $54 \mathrm{mg} \mathrm{GAE} / 100 \mathrm{~g}$ 으로 각각 보고하였다. $\mathrm{Yu}$ 등(28)은 파파야를 과육, 종자, 껍질로 구분하고 폴리페놀 함량을 측정한 결과 각각 $4.67 \mathrm{ug} / \mathrm{mg}, 25.47 \mathrm{ug} / \mathrm{mg}, 7.99$ $\mathrm{ug} / \mathrm{mg}$ 으로 보고하였다. 이와 같이 같은 종류의 과일이라도
폴리페놀 함량에 차이가 나는 것은 품종, 성숙 정도, 기후, 토양, 건조방법, 추출방법 등이 각기 다른데서 비롯된다고 할 수 있다(12). 과일은 비타민 C, E, $\beta$-카로틴과 같은 항산 화 비타민의 주된 공급원이고 free radical 소거작용을 통해 건강에 도움을 준다. 그러나 과일이 나타내는 항산화 효과 의 $80 \%$ 이상은 비타민 이외의 물질에서 비롯되는 것으로, 대표적 성분이 페놀성 물질이며 이들이 free radical 소거능 을 통해 항산화 작용을 나타낸다고 보고된 바 있다(29).

\section{DPPH radical 소거능}

$\mathrm{DPPH}$ 는 짙은 보라색을 나타내는 free radical로 항산화 활성이 있는 물질과 만나면 hydrogen radical의 전자를 받아 들여 노란색으로 탈색되는 특징을 가진다. 색이 엷어지는 정도가 크면 DPPH radical 소거능이 큰 것을 의미한다(30). 열대·아열대 과일의 DPPH radical 소거능을 측정한 결과는 Fig. 1과 같다. 시료 농도 $1 \mathrm{mg} / \mathrm{mL}$ 에서는 $13.52 \sim 61.73 \%$ 로 나타났고 농도 증가에 따라 소거능은 전반적으로 증가하여 $2.5 \mathrm{mg} / \mathrm{mL}$ 에서 $31.46 ~ 92.80 \%, 5 \mathrm{mg} / \mathrm{mL}$ 에서 $43.46 ~ 93.00 \%$ 를 나타내었다. 석류는 모든 농도에서 다른 시료보다 높은 소거능을 보여주었고 $2.5 \mathrm{mg} / \mathrm{mL}$ 이상의 농도에서는 양성 대조군으로 사용한 ascorbic acid의 활성(95.26\%)과 대등하 여 항산화능이 우수한 것으로 나타났는데 $(\mathrm{p}<0.05)$ 이는 폴 리페놀 함량이 높은 것과 상관이 있는 것을 알 수 있다. 반면, 용과는 가장 낮은 활성을 보이며 석류의 $1 / 2$ 에 해당하 는 소거능을 보였다. Rho 등(31)은 석류 메탄올 추출물이

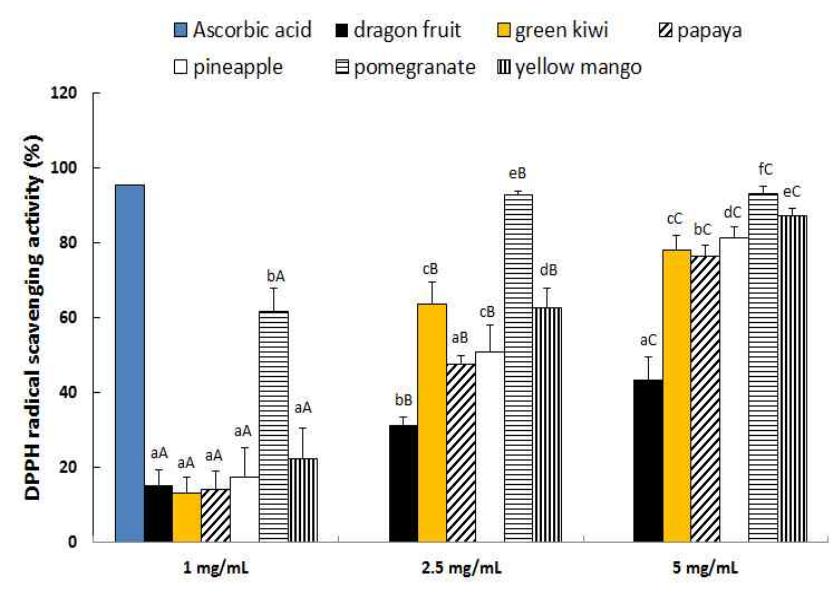

Fig. 1. DPPH radical scavenging activity of imported tropical and subtropical fruits. Values with different small letters are significantly different at $\mathrm{p}<0.05$ among various fruits.

Values with different capital letters are significantly different at $p<0.05$ among concentrations.

Table 1. Total polyphenol contents of imported tropical and subtropical fruits

\begin{tabular}{ccccccc}
\hline & Dragon fruit & Green kiwi & Papaya & Pineapple & Pomegranate & Yellow mango \\
\hline $\mathrm{mg} \mathrm{GAE} / \mathrm{g}$ & $2.45 \pm 0.07^{\mathrm{a}}$ & $2.99 \pm 0.15^{\mathrm{a}}$ & $2.53 \pm 0.26^{\mathrm{a}}$ & $3.77 \pm 0.26^{\mathrm{b}}$ & $12.22 \pm 0.47^{\mathrm{c}}$ & $2.55 \pm 0.15^{\mathrm{a}}$ \\
\hline
\end{tabular}


10 $100 \mathrm{ug} / \mathrm{mL}$ 의 범위에서 농도에 비례하는 DPPH radical 소거작용을 나타내었다고 하였다. Chung 등(32)은 색상별 키위의 DPPH radical 소거능을 측정한 결과 $1 \sim 20 \mathrm{mg} / \mathrm{mL}$ 의 범위에서 농도 비례적으로 유의적인 증가추세를 보이며 $20 \mathrm{mg} / \mathrm{mL}$ 에서 87.12 94.83\%를 나타내었다고 보고하였다. Hossain 등(24)은 파인애플을 물, 에틸아세테이트, 메탄올 로 각각 추출하고 $100 \mathrm{ppm}$ 농도에서 $\mathrm{DPPH}$ 소거능을 측정 한 결과 메탄올 > 에틸 아세테이트 > 물 추출물 순으로 높게 나타났고 이는 폴리페놀 함량과 비례한다고 보고하였 다. 본 실험 결과 총 페놀 함량이 가장 높은 석류에서 $\mathrm{DPPH}$ 소거능이 가장 높게 관찰되었다.

\section{ABTS radical 소거능}

$\mathrm{ABTS}$ 는 potassium persulfate와 반응하여 청록색의 ABTS cation radical $\left(\mathrm{ABTS}^{{ }^{+}}\right)$을 생성하는데 항산화 활성 을 가진 물질로부터 전자를 받으면 무색으로 탈색된다. ABTS cation radical은 물과 유기용매에 모두 용해되므로 친수성 및 소수성 시료의 항산화능 측정에 모두 적용 가능 하여 많이 사용되고 있다(30). 열대·아열대 과일의 ABTS radical 소거능 측정 결과는 Fig. 2와 같다. 시료 농도 1 $\mathrm{mg} / \mathrm{mL}$ 에서는 6.31 38.89\%로 용과, 그린키위, 파파야가 낮 은 소거능을 보였고 석류가 가장 높은 소거능을 보였다 ( $\mathrm{p}<0.05)$. 농도 증가에 따라 소거능은 모든 시료에서 유의적 으로 증가하여 $2.5 \mathrm{mg} / \mathrm{mL}$ 에서 $18.15 ~ 78.40 \%$ 로 나타났고, $5 \mathrm{mg} / \mathrm{mL}$ 에서는 28.16 98.98\%로 석류 > 옐로우망고 > 파인 애플 > 그린키위 > 파파야 > 용과 순으로 나타났다 $(\mathrm{p}<0.05)$. 석류는 소거능이 가장 낮은 용과의 3.5 배 이상이었으며 양 성 대조군인 ascorbic acid(98.23\%)와 대등한 활성이었다. $\mathrm{ABTS}$ 활성은 폴리페놀 함량이 높은 석류에서 가장 높게 나타나 DPPH 소거능과 마찬가지로 총 페놀함량과 연관이

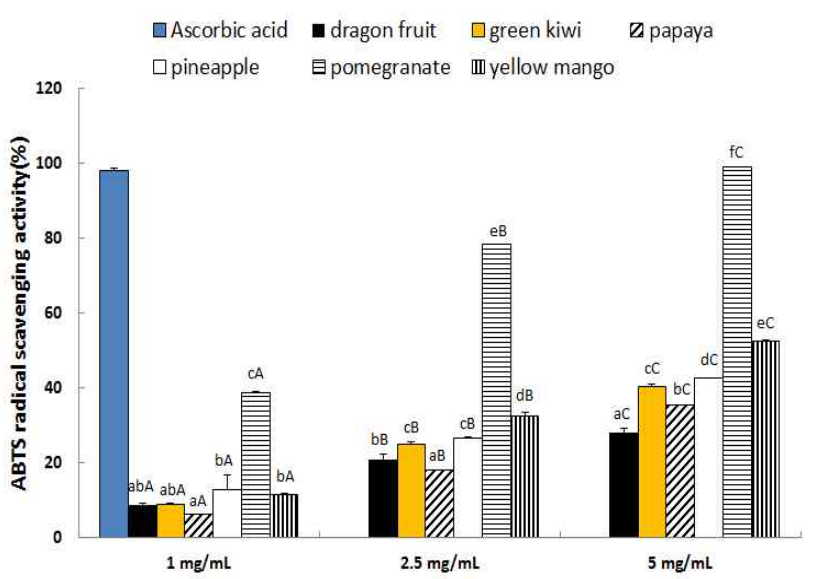

Fig. 2. ABTS radical scavenging activity of imported tropical and subtropical fruits. Different small letters above the bars indicate significantly different at $\mathrm{p}<0.05$ among various fruits.

Different capital letters above the bars indicate significantly different at $p<0.05$ among concentrations.
있는 것을 알 수 있었다.

\section{Superoxide anion radical 소거능}

Superoxide anion radical $\left(\mathrm{O}_{2}{ }^{\circ}\right)$ 은 xanthine oxidase에 의하 여 생성되고 NBT와 반응하여 superoxide anion radical-NBT 복합체를 형성하면 청색을 띠게 되는데 항산화 활성을 갖는 물질에 의해 탈색되는 원리를 이용하여 측정하였다(33). Superoxide anion radical은 hydrogen peroxide $\left(\mathrm{H}_{2} \mathrm{O}_{2}\right)$, hydroxyl radical $\left(\mathrm{OH}^{*}\right)$, singlet oxygen 등의 전구체로 작용 하며 세포 및 신경조직을 손상시키는 독성이 강한 radical이 다(34). 열대·아열대 과일의 superoxide anion radical 소거능 을 측정한 결과는 Fig. 3 과 같다. 시료농도 $1 \mathrm{mg} / \mathrm{mL}$ 에서 석류와 파인애플이 각각 $67.27 \%$ 와 $64.30 \%$ 로 가장 높게 나 타났고 파파야와 그린키위가 각각 $29.34 \%$ 와 $32.58 \%$ 로 가 장 낮게 나타났다. 시료 농도 증가에 따라 소거능은 증가하 는 경향을 보여 $2.5 \mathrm{mg} / \mathrm{mL}$ 에서 $33.11 ~ 81.29 \%, 5 \mathrm{mg} / \mathrm{mL}$ 에 서 $45.86 ~ 86.63 \%$ 로 파파야는 전 농도 범위에서 가장 낮은 소거능을 보였고 석류와 파인애플은 가장 높은 소거능을 보였다(p<0.05). 양성대조군으로 사용한 ascorbic acid는 활 성이 나타나지 않아 본 실험에서 사용한 농도 범위에서는 superoxide anion radical을 포착하는 능력이 없는 것으로 나타났으며 이러한 결과는 Jeong 등(35)의 연구에서 vitamin $\mathrm{C}$, vitamin $\mathrm{E}, \mathrm{BHA}, \mathrm{BHT}$ 등의 상용 항산화제가 superoxide anion radical 소거능을 나타내지 않았다고 보고 한 내용과 유사하였다.

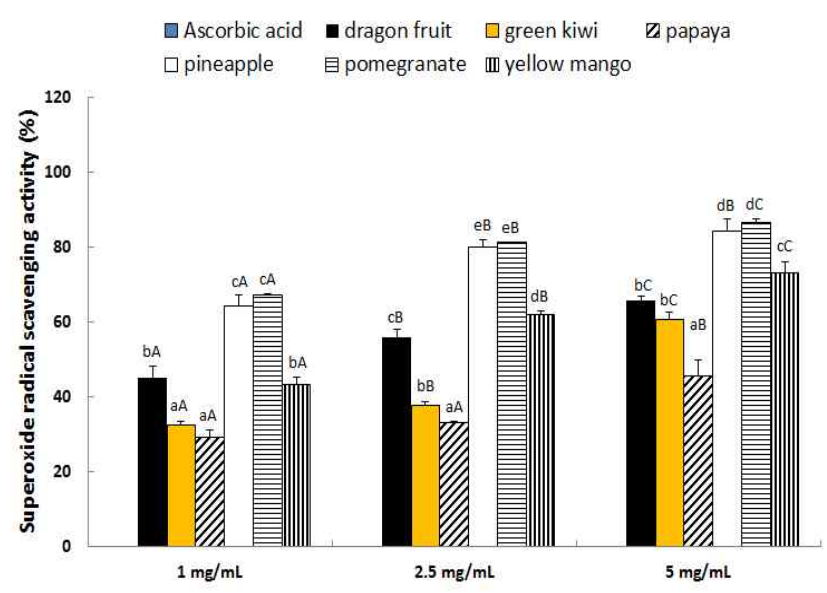

Fig. 3. Superoxide anion radical scavenging activity of imported tropical and subtropical fruits. Different small letters above the bars indicate significantly different at $p<0.05$ among various fruits. Different capital letters above the bars indicate significantly different at $p<0.05$ among concentrations.

\section{FRAP 활성}

FRAP법은 산화·환원 반응을 측정하는 것으로 시료 중에 항산화 물질이 존재하면 노란색의 $\mathrm{Fe}(\mathrm{III})-\mathrm{TPTZ}$ 가 푸른색 의 $\mathrm{Fe}(\mathrm{II})-\mathrm{TPTZ}$ 로 환원되는 원리를 이용하는 것이다(36). 
열대·아열대 과일의 FRAP 활성을 흡광도로 나타낸 결과는 Fig. 4 와 같다. 시료 농도 $1 \mathrm{mg} / \mathrm{mL}$ 에서는 0.02 0.14 abs로 나타났고 $2.5 \mathrm{mg} / \mathrm{mL}$ 에서는 0.05 0.15 abs로 큰 변화가 없었 으나 그 이후의 농도에서 유의적으로 증가하여 $5 \mathrm{mg} / \mathrm{mL}$ 에 서는 0.10 0.37 abs로 파파야가 가장 높았고 그 다음으로 그린키위 > 파인애플 $=$ 석류 $>$ 용과 $>$ 옐로우망고 순이었다 $(\mathrm{p}<0.05)$. Guo 등(37)은 28 종 과일의 FRAP 활성을 측정한 결과 본 실험에 사용한 동일종의 과일에서 키위 > 석류 > 파인애플 > 망고 순으로 높게 나타났다고 보고하여 본 실험의 결과와 유사한 경향을 보였다. 이 같이 항산화 실험 방법에 따라 시료의 활성 정도가 다르게 나타나는 것은 항산화 실험마다 측정 원리와 반응 mechanism이 각기 다르 고 특정 성분에 대한 반응 정도가 다르기 때문인 것으로 보고되고 있다(36). 따라서 시료의 항산화 활성을 평가하려 면 두 가지 이상의 방법으로 평가하기를 권장하고 있다 $(27,36)$.

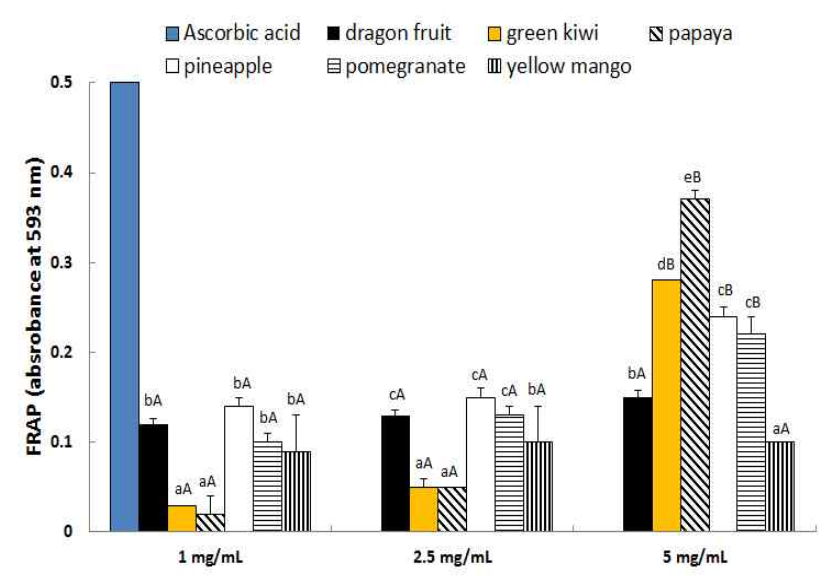

Fig. 4. FRAP of imported tropical and subtropical fruits. Different small letters above the bars indicate significantly different at $\mathrm{p}<0.05$ among various fruits.

Different capital letters above the bars indicate significantly different at $p<0.05$ among concentrations.

\section{Tyrosinase 저해 효과}

피부에 존재하는 흑색색소인 melanin은 표피세포의 melanocyte에서 tyrosinase를 핵심효소로 하여 tyrosine으로 부터 생 합성된다. 피부에 적당량 존재하는 melanin은 자외 선과 활성산소로부터 피부를 보호하는 역할을 하지만 과도 한 생성은 색소침착으로 이어지고 피부 노화를 촉진시키며 피부암 유발의 원인이 되기도 한다(38). 한번 생성된 멜라닌 은 쉽게 파괴 또는 분해되기 어렵기 때문에 melanin 합성의 주효소인 tyrosinase 활성을 저해하는 물질의 탐색 연구가 이루어지고 있다(38). Mushroom tyrosinase 효소를 이용하 여 열대·아열대 과일의 tyrosinase 저해 효과를 측정한 결과 는 Fig. 5 와 같다. 시료 농도 $1 \mathrm{mg} / \mathrm{mL}$ 에서는 그린키위가 $29.61 \%$ 로 가장 낮았고 석류가 $44.09 \%$ 로 가장 높았다. 농도
증가에 따라 저해효과의 증가는 미미하여 $2.5 \mathrm{mg} / \mathrm{mL}$ 에서 $39.79 \sim 53.79 \%, 5 \mathrm{mg} / \mathrm{mL}$ 에서 $45.72 \sim 67.28 \%$ 를 나타내었으 며 그 중 석류, 파인애플, 용과가 다른 시료보다 높은 활성을 나타내었다(p<0.05). Shin 등(40)은 참외 추출물의 tyrosinase 저해활성을 측정한 결과 $1,000 \mathrm{ppm}$ 에서는 tyrosinase 저해 활성이 나타나지 않았고 $10,000 \mathrm{ppm}$ 에서 껍질 $17.71 \%$, 과 육 $16.81 \%$, 태좌 $12.59 \%$ 를 보이며 각 부위별로 $20 \%$ 이하의 낮은 저해효과를 나타내었다고 보고하였다(40). Chung 등 의 연구(32)에서 gold, green, red 키위의 tyrosinase 저해 효 과는 농도 증가에 따라 증가하는 경향을 나타내어 $5 \mathrm{mg} / \mathrm{mL}$ 에서 $35.17 \sim 43.11 \%, 10 \mathrm{mg} / \mathrm{mL}$ 에서 $44.09 \sim 50.00 \%, 20$ $\mathrm{mg} / \mathrm{mL}$ 에서 $57.06 ~ 86.76 \%$ 를 나타내었고 총 페놀 함량이 높은 순으로 저해효과가 높았다고 보고하여 본 실험의 결과 와는 다소 차이를 보였다.

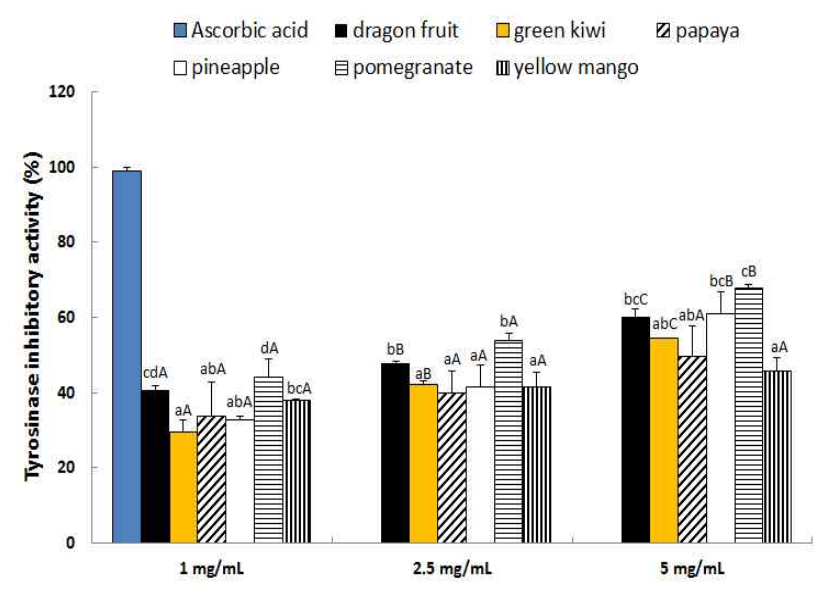

Fig. 5. Tyrosinase inhibitory activity of imported tropical and subtropical fruits. Different small letters above the bars indicate significantly different at $\mathrm{p}<0.05$ among various fruits.

Different capital letters above the bars indicate significantly different at $p<0.05$ among concentrations.

환원력

환원력은 항산화 활성과 관련이 있는 중요한 인자이다. Potassium ferricyanide를 이용하여 형성된 ferric ion $\left(\mathrm{Fe}^{3+}\right)$ -ferricyanide 복합체는 시료 중에 존재하는 항산화 물질에 의해 ferrous $\left(\mathrm{Fe}^{2+}\right)$ 상태로 환원되면서 푸른색을 띠게 되고 이 때의 흡광도로 항산화 활성을 측정한다 $(5,30,33)$. 열대. 아열대 과일의 환원력을 측정한 결과는 Fig. 6 과 같다. 시료 농도 $1 \mathrm{mg} / \mathrm{mL}$ 에서는 석류가 $0.42 \mathrm{abs}$ 로 가장 높았고 파인애 플이 $0.17 \mathrm{abs}$ 로 그 다음 순으로 높았다. 시료 농도 증가에 따라 환원력은 유의적으로 증가하여 $2.5 \mathrm{mg} / \mathrm{mL}$ 에서 $0.24 \sim 0.98 \mathrm{abs}$ 를 나타내었고 $5 \mathrm{mg} / \mathrm{mL}$ 에서는 용과가 0.34 $\mathrm{abs}$ 로 가장 낮았고 석류가 $1.28 \mathrm{abs}$ 로 용과보다 3.7 배 이상 의 환원력을 보이며 가장 높게 나타났으며 양성대조군인 ascorbic acid(1.25 abs)와 대등하였다( $\mathrm{p}<0.05)$. 이로써 석류 는 $\mathrm{Fe}^{3+}$ 를 효과적으로 환원시키는 것을 알 수 있었다. 본 
실험 결과 환원력은 페놀 함량이 높은 시료에서 높게 나타 나 DPPH radical 소거능에서와 마찬가지로 페놀 함량과 상관관계가 높은 것으로 보인다.

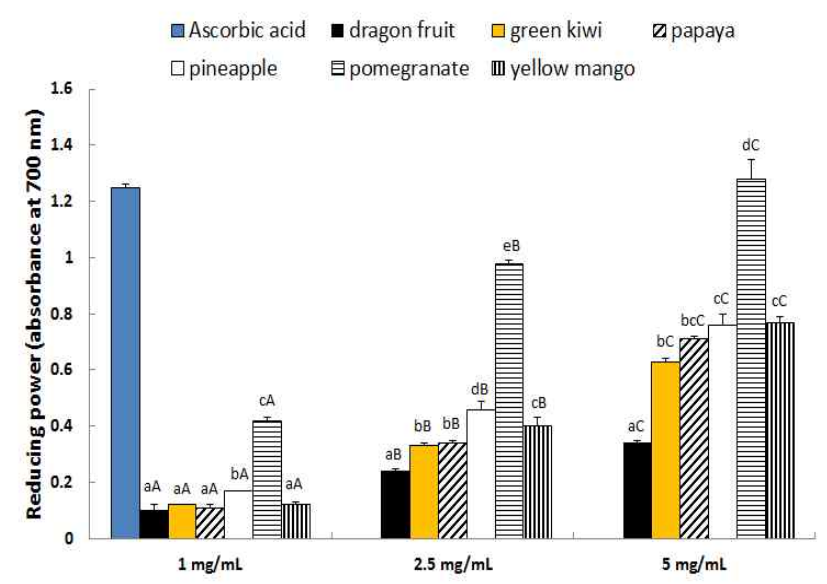

Fig. 6. Reducing power of imported tropical and subtropical fruits. Different small letters above the bars indicate significantly different at $\mathrm{p}<0.05$ among various fruits.

Different capital letters above the bars indicate significantly different at $\mathrm{p}<0.05$ among concentrations.

\section{요 약}

본 연구에서는 수입산 열대·아열대 과일의 항산화 효과 를 비교하기 위하여 총 폴리페놀 함량, DPPH radical 소거 능, ABTS radical 소거능, superoxide anion radical 소거능, FRAP 활성, tyrosinase 저해효과, 환원력 등을 측정하였다. 총 폴리페놀 함량은 석류가 $12.22 \mathrm{mg} \mathrm{GAE} / \mathrm{g}$ 으로 가장 높았 고 그 다음 순으로 파인애플이 $3.77 \mathrm{mg} \mathrm{GAE} / \mathrm{g}$ 이었으며, 용과, 그린키위, 파파야, 옐로우망고가 $2.45 ~ 2.99 \mathrm{mg} \mathrm{GAE} / \mathrm{g}$ 의 범위로 나타났다. 석류는 DPPH, ABTS, superoxide anion radical 소거능, 환원력에서 다른 과일보다 높은 활성을 보 여주었고 그 다음으로 파인애플이 높은 활성을 보였다. 특 히 석류는 추출물의 농도가 증가함에 따라 전반적으로 활성 이 증가하는 경향을 보였고 시료 농도 $5 \mathrm{mg} / \mathrm{mL}$ 에서는 DPPH radical 소거능과 ABTS radical 소거능 및 환원력이 양성대조군으로 사용한 ascorbic acid와 대등한 효과를 보였 다. 반면에, 용과와 파파야는 대부분의 항산화 효과 실험에 서 낮은 활성을 나타내었다.

\section{감사의 글}

이 논문은 2015학년도 대진대학교 학술연구비 지원에 의하여 수행되었기에 이에 감사드립니다.

\section{References}

1. Park SH, Hwang HS, Han JH (2004) Development of drink from composition with medicinal plants and evaluation of its physiological function. Korean J Nutr, $37,364-372$

2. Jeong CH, Choi SG, Heo HJ (2008) Analysis of nutritional compositions and antioxidative activities of Korean commercial blueberry and raspberry. J Korean Sci Food Sci Nutr, 37, 1375-138

3. Moo-Huchin VM, Estrada-Mota I, Estrada-Leon R, Cuevas-Glory L, Ortiz-Vazquez E, Vargas MLV, Betancur-Ancona D, Sauri-Duch E (2014) Determination of some physicochemical characteristics, bioactive compounds and antioxidant activity of tropical fruits from Yucatan, Mexico. Food Chem, 152, 508-515

4. Yahia EM, Gutierrez-Orozco F, Arvizu-de Leon C (2011) Phytochemical and antioxidant characterization of the fruit of black sapote (Diospyros digyna Jacq.). Food Res Int, 44, 2210-2216

5. Lee MY, Yoo MS, Whang YJ, Jin YJ, Hong MH, Pyo YH (2012) Vitamin C, total polyphenol, flavonoid contents and antioxidant capacity of several fruit peels. Korean J Food Sci Technol, 44, 540-544

6. Spínola V, Pinto J, Castilho PC (2015) Identification and quantification of phenolic compounds of selected fruits from Madeira island by HPLC-DAD - ESI-MSn and screening for their antioxidant activity. Food Chem, 73, 14-30

7. Lim YY, Lim TT, Tee JJ (2007) Antioxidant properties of several tropical fruits : a comparative study. Food Chem, 103, 1003-1008

8. Halliwell B (1996) Antioxidants in human health and disease. Ann Rev Nutr, 16, 33-50

9. Kim AR, Lee HJ, Jung HO, Lee JJ (2014) Physicochemical composition of ramie leaf according to drying methods. J Korean Soc Food Sci Nutr, 43, 118-127

10. Rufino MSM, Alves RE, Brito ES, Pérez-Jiménez J, Saura-Calixto F, Mancini-Filho J (2010) Bioactive compounds and antioxidant capacities of 18 non-traditional tropical fruits from Brazil. Food Chem, 121, 996-1002

11. Lee WJ, Lee TM (2013) An exploratory study on consumer behavior on imported agro-product : focused on imported fruit. J Consumer Policy Studies 44, 1-25

12. Martínez R, Torres $P$, Meneses MA, Figueroa JG, Pérez-Álvarez JA, Viuda-Martos M (2012) Chemical, 
technological and in vitro antioxidant properties of mango, guava, pineapple and passion fruit dietary fibre concentrate. Food Chem, 135, 1520-1526

13. Bicas JL, Molina G, Dionisio AP, Cavalcante-Barros FF, Wagner R, Marostica MRJr (2011) Volatile constituents of exotic fruits from Brazil. Food Res Int, 44, 1843-1855

14. Dewanto V, Wu X, Liu RH (2002) Processed sweet corn has higher antioxidant activity. J Agric Food Chem, 50, 4959-4964

15. Blois MS (1958) Antioxidant determinations by the use of a stable free radical. Nature, 181, 1199-1200

16. Re R, Pellegrini N, Proteggente A, Pannala A, Yang M, Rice-Evans C (1999) Antioxidant activity applying an improved ABTS radical cation decolorization assay. Free Radic Biol Med, 26, 1231-1237

17. Wang J, Yuan X, Jin Z, Tian Y, Song H (2007) Free radical and reactive oxygen species scavenging activities of peanut skins extract. Food Chem, 104, 242-250

18. Benzie IFF, Strain JJ (1996) The ferric reducing ability of plasma as a measure of "antioxidant power": the FRAP assay. Anal Biochem, 239, 70-76

19. Chang MI, Kim JY, Kim US, Baek SH (2013) Antioxidant, tyrosinase inhibitory, and anti-proliferative activities of gochujang added with cheonggukjang powder made from sword bean. Korean J Food Sci Technol, 45, 221-226

20. Wong JY, Chye FY (2009) Antioxidant properties of selected tropical wild edible mushrooms. J Food Compos Anal, 22, 269-277

21. Kim EJ, Choi JY, Yu M, Kim MY, Lee S, Lee BH (2012) Total polyphenols, total flavonoid contents, and antioxidant activity of Korean natural and medicinal plants. Korean J Food Sci Technol, 44, 337-342

22. Cha JY, Kim HJ, Chung CH, Cho YS (1999) Antioxidative activities and contents of polyphenolic compound of Cudrania tricuspidata. J Korean Soc Food Sci Nutr, 28, 1310-1315

23. Kalt W, Hanneken A, Milbury P, Tremblay F (2010) Recent research on polyphenolics in vision and eye health. J Agric Food Chem, 58, 4001-4007

24. Hossain MA, Rahman SMM (2011) Total phenolics, flavonoids and antioxidant activity of tropical fruit pineapple. Food Res Int, 44, 672-676

25. Ozgen M, Durgac C, Serce S, Kaya C (2008) Chemical and antioxidant properties of pomegranate cultivars grown in the mediterranean region of Turkey. Food Chem, 111, 703-706
26. Liu FX, Fu SF, Bi XF, Chen F, Liao XJ, Hu XS, Wu JH (2013) Physico-chemical and antioxidant properties of four mango (Mangifera indica L.) cultivars in China. Food Chem, 138, 396-405

27. Patthamakanokporn O, Puwastien P, Nitithamyong A, Sirichakwa PP (2008) Changes of antioxidant activity and total phenolic compounds during storage of selected fruits. J Food Compos Anal, 21, 241 - 248

28. Yu MH, Lee SG, Im HG, Chae IG, Kim HJ, Lee J, Lee IS (2011) Antioxidant capacity and quinone reductase activity of methanol extracts and fractions from papaya seed. J Life Sci, 21, 775-782

29. Miller NJ, Rice-Evans CA (1997) The relative contributions of ascorbic acid and phenolic antioxidants to the total antioxidant activity of orange and apple. Food Chem, 60, 331-337

30. Kim MJ, Park E (2011) Feature analysis of different in vitro antioxidant capacity assays and their application to fruit and vegetable samples. J Korean Soc Food Sci Nutr, 40, 1053-1062

31. Roh BK, Kim JY, Kim JY (2005) Anti-oxidant activities of Punica granatum extracts. J Soc Cosmet Scientists Korea. 31, 207-212

32. Chung HJ, Kim CJ, Choi YS (2015) Comparison of antioxidant and nitrite scavenging activities of different colored kiwis cultivated in Korea. J Korean Soc Food Cult, 30, 220-226

33. Gülçin I (2006) Antioxidant activity of caffeic acid (3,4-dihydroxycinnamic acid). Toxicology, 217, 213-220

34. Jin SY (2011) Study on antioxidant activities of extracts from different parts of Korean and Iranian pomegranates. J Korean Soc Food Sci Nutr, 40, 1063-1072

35. Jeong SJ, Lee H, Song HN, Seong NS, Lee SE, Baeg NI (2004) Screening for antioxidant activity of plant medicinal extracts. J Korean Soc Appl Biol Chem, 47, 135-140

36. Lee YJ, Kim JH, Oh JW, Shin GH, Lee JS, Cho JH, Park JJ, Lim JH, Lee OH (2014) Antioxidant and anti-adipogenic effects of kohlrabi and radish sprout extracts. Korean J Food Sci Technol, 46, 531-537

37. Guo C, Yang J, Wei J, Li Y, Xu J, Jiang Y (2003) Antioxidant activities of peel, pulp and seed fractions of common fruits as determined by FRAP assay. Nutr Res, 23, 1719-1726

38. Lee HJ, Do JR, Kwon JH, Kim HK (2010) Physiological activities of Cucurbita moschata Duch. extracts with different extraction conditions J Korean Soc Food Sci 
Nutr, 39, 165-171

39. Shin YS, Lee JE, Yeon IK, Do HW, Cheung JD, Kang CK, Choi SY, Youn SJ, Cho JG, Kwoen DJ (2008)
Antioxidant effects and tyrosinase inhibition activity of oriental melon (Cucumis melo L. var makuwa Makino) extracts. J Life Sci, 18, 963-967 